\title{
Incentives to retain late 19th century housing and the practicalities of conservation and repair of that stock
}

\author{
B. J. Hickson \\ Bathurst Regional Council, Australia
}

\begin{abstract}
Heritage incentives encourage the conservation and repair of late 19th-early 20th century housing, but what are the practicalities of conservation and repair, based on our particular housing stock for the owner home handyman?

This paper summarises the types of incentives used to encourage the conservation and repair of late 19th century and early 20th century housing, the most successful of these incentives being a free heritage advisory service and small grants.

The practical problems of saving this type of housing stock and readapting it for modern sustainable living are then examined through the application of a case study - the restoration and extension of a typical late Victorian small masonry residence in NSW Australia. The problems encountered and methods used in this 'hands on' process provide a guide for house owners planning on restoring an older house. The experience highlights the difficulties that arise during the process. This paper provides guidance for the owner restorer from a heritage adviser involved in a similar project.

Areas covered include assessing significance, developing a sustainable design, demolition of unwanted fabric and hazardous materials, repairs to brickwork, rendered surfaces, paint and wall paper and installing services.

Keywords: late 19th/20th century heritage masonry houses, practical conservation and repair, re-use of heritage housing stock, incentives.
\end{abstract}

\section{Introduction}

Research recently completed by a colleague - Sinclair Croft (an unpublished thesis which has been presented in Australia and in NZ) lists the various heritage 
incentives used locally and internationally, through information gathered on line and via questionnaires, to encourage the maintenance and conservation of late Victorian and early Federation (Edwardian) buildings- principally houses. Lists of incentives were compiled and some new incentives suggested.

The two most common incentives in NSW are

- $\quad$ Heritage advisory service and

- Small grants program.

As a heritage adviser the author has been involved in the delivery of these two services in the Bathurst Regional Council (BRC), in central NSW Australia, for 16 years. The small grants program at Bathurst has run for 15 years and is the most successful of its type in NSW.

Through the practical application of a case study - a late Victorian masonry residence, the most common problems raised with the HA service were examined in practice.

\section{Heritage incentives}

Heritage incentives are provided to encourage the retention and conservation of heritage assets. Houses of the Victorian and early 20th Century make up a large proportion of the locally listed heritage items. In Bathurst Region they comprise approximately $50 \%$ of the heritage assets and in the adjacent Mid Western Regional Council area $56 \%$ of the listed assets are houses. Sinclair Croft's findings were that the following incentives were employed:

- Free heritage advice

- Heritage trade directory

- Advice on insurance

- Waving development application fees

- Rate relief

- Local heritage grants

- State heritage grants

- Recognition of good heritage results through an awards systems

- Education through seminars and brochures

- Specific planning incentives such as relaxed parking requirements and higher density ratios on land were allowed if heritage items were retained and conserved.

Additionally, the following incentives were proposed for future consideration

- $\quad$ Free maintenance service

- Minor works free for pensioners, rather than grant schemes

- $\quad$ Free hire of scaffolding

- Encourage adaptive re-use of buildings. 


\subsection{Heritage funding}

Typical of many NSW councils, Bathurst Regional Council offers a heritage fund each year generally directed at repairs and maintenance of heritage house of late Victorian and early Federation period. What is not typical is the success of the fund. This fund was first offered in 1998/9 with $\$ 10,000$ available with most grants being less than $\$ 1000$. This fund is now offering $\$ 60,000$ per annum and is seen as a very useful incentive to heritage owners. Most applicants are also given free heritage advice to ensure they are carrying out the work in the best way possible.

\subsection{The growth of the Bathurst heritage fund}

The growth of the Bathurst heritage fund is shown in Table 1.

Table 1: $\quad$ Growth of the Bathurst heritage fund.

\begin{tabular}{|c|c|c|c|c|}
\hline \multirow[t]{2}{*}{ Year } & \multicolumn{2}{|c|}{$\begin{array}{l}\text { Applications } \\
\text { Received }\end{array}$} & \multirow{2}{*}{$\begin{array}{c}\text { Heritage } \\
\text { Fund } \\
\text { budget }\end{array}$} & \multirow{2}{*}{$\begin{array}{c}\text { No. of } \\
\text { Projects } \\
\text { offered } \\
\text { funding }\end{array}$} \\
\hline & No. & Value & & \\
\hline 1998/99 & 9 & $\$ 40,278$ & $\$ 10,000$ & 9 \\
\hline $1999 / 2000$ & 20 & $\$ 87,167$ & $\$ 10,000$ & 20 \\
\hline 2000/01 & 26 & $\$ 81,448$ & $\$ 10,000$ & 26 \\
\hline $2001 / 02$ & 45 & $\$ 212,462$ & $\$ 10,000$ & 35 \\
\hline $2002 / 03$ & 33 & $\$ 150,256$ & $\$ 15,000$ & 31 \\
\hline $2003 / 04$ & 39 & $\$ 210,205$ & $\$ 15,000$ & 37 \\
\hline $2004 / 05$ & 43 & $\$ 436,655$ & $\$ 37,500$ & 43 \\
\hline $2005 / 06$ & 56 & $\$ 350,000$ & $\$ 37,500$ & 50 \\
\hline $2006 / 07$ & 49 & $\$ 374,000$ & $\$ 37,500$ & 48 \\
\hline $2007 / 08$ & 75 & $\$ 574,700$ & $\$ 37,500$ & 70 \\
\hline 2008/09 & 59 & $\$ 500,000$ & $\$ 37,500$ & 59 \\
\hline $2009 / 10$ & 53 & $\$ 335,000$ & $\$ 45,000$ & 50 \\
\hline $2011 / 12$ & 107 & $\$ 918,798$ & $\$ 48,000$ & 69 \\
\hline $2012 / 13$ & 116 & $\$ 964,777$ & $\$ 60,000$ & 104 \\
\hline TOTAL & 811 & $\$ 5,835,746$ & $\$ 459,000$ & 726 \\
\hline
\end{tabular}

Statistics above prepared by Janet Bingham, Manager Strategic Planning for Bathurst Regional Council. 1989/99 to 2003/04 fund under the former Bathurst City Council.

The Heritage Fund budget includes BRC and NSW Heritage Branch contribution.

From year to year unspent funds were rolled over into the next year.

The rollover amount is not shown in this table. 


\subsection{Heritage advice}

There are over 40 heritage advisers in NSW providing a 'free' heritage service through local councils. They come from different disciplines such as architects, historians and archaeologists. Their experience and expertise is varied. When advice is given in combination with grant funds it is more effective.

The advice is generally based on a combination of 'text book' information mixed with years of advisory experience. But 'hands on' experience is a useful tool when it comes to giving practical advice to those restoring an old house, often for the first time, often as home handymen.

\subsection{The case study}

The opportunity arose in the town of Mudgee to purchase a small late Victorian town house named Villa Laura for the purpose of restoration, conservation and extension, as a learning experience where 'best practice' could be coupled with practicality. The experience that followed highlighted

1. The process that should be followed. - where to start - is a frequent question.

2. The problems that amateur home restorers may be faced with, and

\section{Investigation of significance}

It is important to first discover the significance of the house before changing it. In practice the easiest way to start is to gather as much documented information as practicable about the place and then summarise it.

The Burra Charter (Australian Guide document for heritage works) lists various aspects to think about when collecting this information including 'the aesthetic, historic, scientific, social or spiritual values for past, present or future generations'. The significance is 'embodied in the place itself, its fabric, setting, use, associations, meanings, records, related places and related objects.'

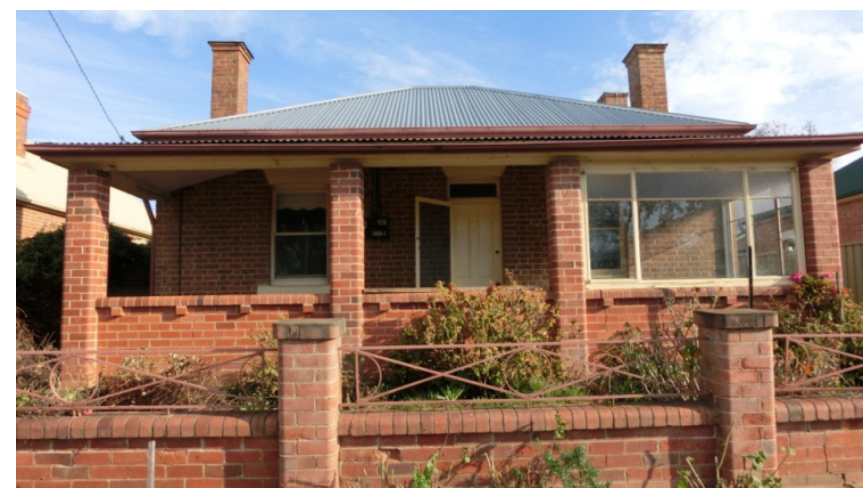

Figure 1: $\quad$ The case study. Villa Laura street façade. 
The history of a typical house might include:

- Past residents or owners and their activities

- The builder and/or designer

- The aesthetics and contribution the house makes to the streetscape

- $\quad$ Any special events associated with the place or adjacent spaces.

\subsection{Documented history}

The history of the house will be in written documents, photographs and maps, and in the building fabric. Opportunities for the lay-person to gather history include:

- Local historical society

- Parish Maps (on line) - they will tell you who the first owner of the land was. First land holders are often land speculators.

- Rate books (Historical Society or local Council) may tell you about who has lived here.

- Newspaper files ('Trove.com') may tell you about events associated with the house - especially once you have a name or names, or events, to connect with the place.

- Historic deeds. (There are many 'old system' land deeds languishing in solicitor's filing systems.)

- Photographs of the house or the neighbourhood.

- The neighbours, current and past.

\subsection{Physical evidence}

History is also revealed in examining the building fabric. Detailed inspections of the building might reveal more information about:

- $\quad$ The style, construction and original date.

- Later alterations and progressive changes made to a property. As work progresses the owner will be become more aware of the history of the house and where conservation or repair works are needed.

- Measured drawings will be useful and necessary if alterations and /or additions are proposed.

- Construction details e.g. Roof construction - style, materials and method. (e.g. timbers in the round will suggest very early to mid Victorian construction, and some earlier materials may have been left behind such as timber shingles.)

- Brickwork: the bricks used: their bond, joint, colour, frog. The construction of headers and sills. Bricklayers tended to stay with the same style - a change in brick type of bond can indicate another stage in construction.

- Windows, doors, skirtings - details of the joinery and hardware

- $\quad$ Old newspapers under floor coverings and in wall or ceiling gaps.

- Items under the floor boards! 


\subsection{The case study history}

Historical research revealed that Villa Laura was a deceased estate formerly owned by Laura Wallace, a spinster, who had lived here for 44 years. Her legal files contained many earlier land transactions and copies of wills where the property had passed on to descendants. Newspaper articles corroborated and added to the information. In summary:

Built in 1892 on land released as a house block in 1852, the house is typical of a modest late Victorian home. The original 4 rooms plus rear attached kitchen was built for Mr. John Muller, a wine grower in the district, as a future gift to his daughter Louisa. John married Louisa Roth, the daughter of another wine grower and they had six sons. They would inherit John's extensive wine growing properties. John decided to make special provisions for his daughters by constructing a house each for them in Mudgee. On his death his wife Louisa took up residence in this house and when she died, in 1927, the house passed onto her daughter Louisa.

When Louisa inherited this house she was already established on a rural property with her husband. So it was only when her husband retired that they moved into the town house. In the meantime it was rented out. Louisa sons inherited the house on her death and sold it in 1962 to $\mathrm{Mr}$ and Mrs George Gorrie. They made improvements and sold the house to Ms. Laura Wallace.

Physical evidence revealed further detail of the house history as follows:

1882 - The 5 roomed Victorian house with front and back verandah was built in Flemish Bond in red pressed smooth bricks, locally made.

Late 1930s - an Art deco appearance was given to the house with new brick columns and balustrade on the front verandah, a side entry and a matching front fence. A rear extension of a small wc room-replaced the rear backyard wc.

1962 - A bathroom and laundry were added, plus the enclosure of the eastern rear verandah to form a 'living room'. The brick bond of the new bathroom and Laundry matched the existing house with no cavity. Newspapers stuffed into a door jamb cavity were dated 1962. Cracks opened up between the brick stages opened up due to uneven settlement.

Later demolition of the enclosed verandah revealed a cache of coins, beneath the rear kitchen threshold. The coins dating from 1917 to 1961 were additional evidence of the 1962 addition!

\subsection{A statement of significance}

A precise statement of why the place is significant should follow based on the research. In the case study:

The house is significant as a typical but modest example of a country town house of late Victorian era. Built in 1892 for Mr. John Muller, a successful early wine grower in the district, the house was a planned future gift to his daughter Louisa. The house remained in family hands for 70 years then sold onto to the Gorrie family who constructed additions. They sold to Laura Wallace, a spinster and well known local historian. 
The most significant part of the fabric was assessed as being the original Victorian house of five rooms (see Figure 2). Later additions, at the rear and an altered front verandah, were assessed as being of little or no significance. The additions were not well constructed and the front verandah alterations were unsympathetic, altering the character of the facade.

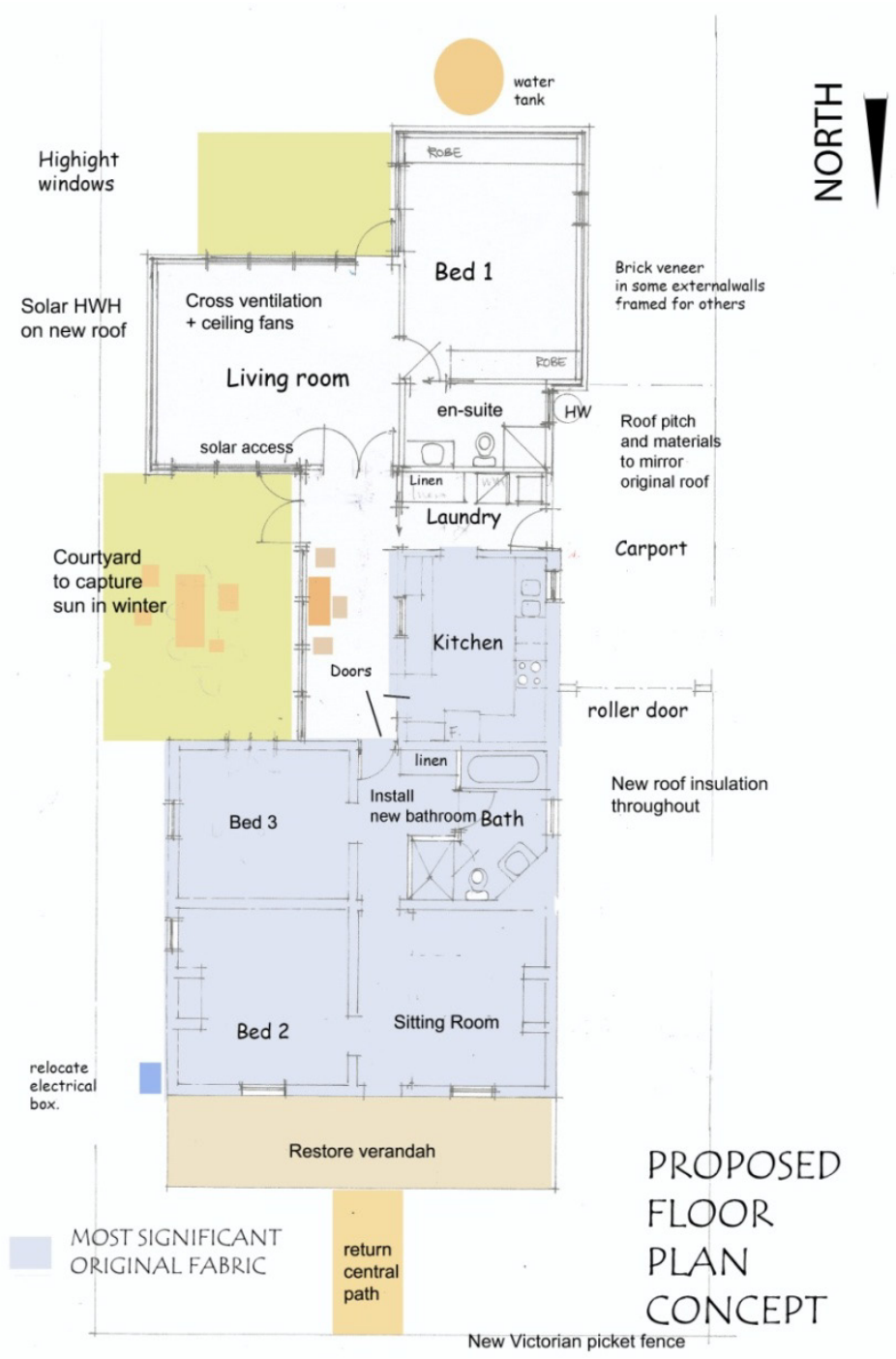

Figure 2: Villa Laura sketch plan above showing areas of heritage significance and proposed energy efficient, sustainable additions. 


\section{Sustainable living: plans for extensions and alterations}

One of the good reasons for re-using heritage buildings is the sustainable nature of the process - re-using what is there rather than re-building.

Some parts of houses will not be readily suitable for modern environmentallyfriendly living. Through the process of ascertaining significance we can arrive at a decision as to which parts should be retained and what can be demolished or altered. Then sketch plans can be developed to accommodate future living.

Sketch plans and working drawings for the alterations and additions should be both sympathetic to the past and accommodate a good style of modern sustainable living. Plans must be submitted to your local council for approval prior to commencing work.

\subsection{Aspects to consider in the proposed alterations and additions}

Water: Water saving devices such as rainwater tanks, grey water re-use and water saving taps.

Thermal comfort: Insulation the new work and added to the existing building. Consider energy efficiency in the design, its compactness, materials, and cross ventilation in summer for cooling.

Energy: Orientation - in Australia, a northern aspect to gain northern sunlight in winter and limit summer sunshine. Consider solar cells for power generation and water heating using sustainable systems such as gas or solar energy.

\subsection{The case study plan}

Villa Laura is a poorly oriented residence facing north in fair physical condition. Except for the front verandah most sunlight was excluded from the house. No insulation existed in walls, floor or ceiling and the house is cold in winter but generally cool in summer. Additions needed to correct this aspect and improve overall energy efficiency.

\section{Demolition}

The investigation of significance and the planning process that followed dictated what could or should be demolished to make way for new works. It was carried out in two stages:

\subsection{Asbestos removal and other hazards}

This is a specialist field unless the quantity is small. If less than 10 sq.m an owner builder can carefully remove asbestos, wrap it and make arrangements for it to be accepted at the tip. (The local council will have instructions.) Otherwise, a specialist firm must be engaged. They will dismantle, wrap and remove the asbestos, and will take all necessary precautions including notifying all those in your immediate neighbourhood. There may still be work the owner must carry out in preparation, such as removal of wall paper so that fixings are exposed. 


\subsection{General demolition}

General demolition follows to remove any unwanted fabric. While this too may be done by specialists it is important for the owner to check

- $\quad$ That the building parts can be separated (removing any joining elements carefully e.g. toothed in bricks, tie rods)

- That dust shields or covers are in place.

Demolition revealed further information about the place.

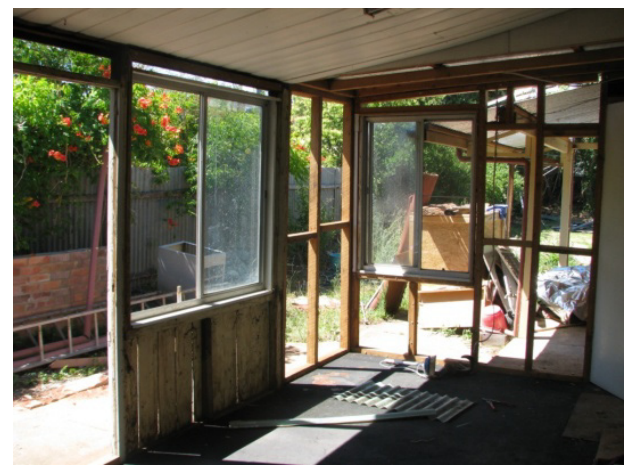

Figure 3: $\quad$ Asbestos linings removed from the eastern enclosed verandah.

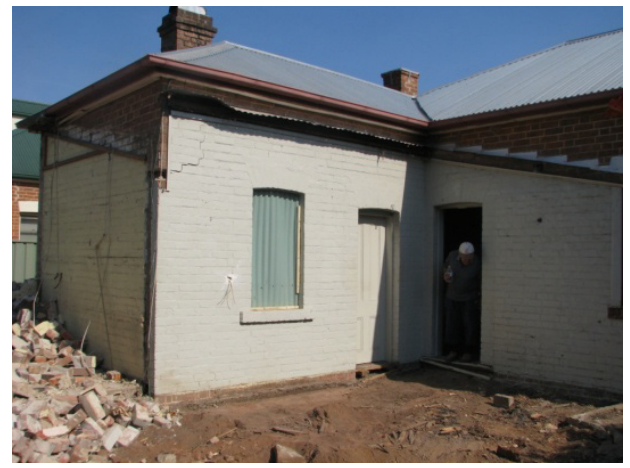

Figure 4: $\quad$ All unwanted additions removed. Note crack in brickwork top LH wall where a brick was toothed into the additions.

\section{Conservation and restoration}

\subsection{Brick walls}

Bricklayers generally had a standard way of bricklaying. Changes in the way the bricks were laid - their bond and joints will indicate different bricklayers and different dates. Also the brick colour and style - pressed or extruded bricks, stamped frogs. Most houses prior to c. 1910 were built in solid brick without a cavity. Victorian brick styles will include 
a. English bond: a line of headers and a line of stretches, alternating

b. Flemish bond, header and stretcher alternating on each course.

c. Garden wall bond (a combination of Flemish or English with 3 or 4 plain stretcher courses in between.

Also note any vertical cracks or brickwork joints. Change will indicate a change in date of the construction. One exception to this is the use of Flemish front walls and English bond side walls. This was common practice in many NSW Victorian houses. Flemish was a more expensive method and so was used to 'dress up' the front facade of the house. Tuck pointing was rarer and denoted a 'quality' house, and was usually restricted to the front elevation.

\subsection{Rising damp}

Almost all Victorian houses in NSW suffer from rising damp due to inadequate foundations and a lack of damp proof course. Some are lucky enough to have a blue stone or slate foundation course. Rising damp is best treated with improved ventilation. Insertion of a new DPC is both very expensive and still leaves 'salts' in the walls above the new DPC. If a wall has been affected by rising damp then there may be drummy render on the inside and rotted skirting boards. Such walls should be treated with a poultice before re applying paint or wall paper. A proprietary brand poultice is 'Cocoon' distributed by Westox Building Products.

\subsection{Pointing up}

Rising damp causes deterioration and fretting of the lower mortar joints.

At Villa Laura many repairs had been carried out to this brickwork. The most obvious intervention was the rendering of the lower 10 courses, rather than pointing up, forming a dado line to the house on the sides. Above this dado line there were many small repairs. Some traditional type mortar, other in cement rich mortar. On the eastern side the mortar was again fretting above the dado line.

The joints were pointed up using a ready mix traditional mortar. A propriety product by Westox called 'Coarse Stuff'- a mixture of triple washed sand, slaked lime and pozzalanic additive. A relatively dry mix and easy enough for a lay person to apply, pushing the mortar into the joints, then, after $1 / 2$ hour, ironing or striking the joint - preferably to match the original. It dries lighter however and the face brickwork should be cleaned down as soon as possible.

\subsection{Underfloor ventilation}

Underfloor ventilation may be inadequate. If floors are to be repaired take the opportunity to check and increase the underfloor ventilation if needed. Solar fans can also be considered.

\subsection{Roof and chimneys}

Removing chimneys really detracts from the heritage significance of the house. If a fire place can't remain in use, consider alternatives, such as installing a modern slow combustion fuel burner, a gas heater or facing the fire place off. The fire places must be sealed off at roof level to prevent vermin and birds 
entering but allowing some ventilation. In Villa Laura a new kitchen stove (electric) was selected to fit into the original kitchen fire place. New additions to the roof should follow similar pitch and lines to the existing. The original house has presently no access to the roof space. This will be inserted so that insulation can be added to existing roof spaces.

\subsection{Windows, doors and skirtings}

Victorian windows are not properly sealed. They are a constant source of draft in winter. If they can't be retrofitted with side beads to reduce draft, change to double glazing retaining as much original fabric as possible.

Panelled timber doors will usually be repairable, but may need stripping and repairs. Often old Victorian doors are below the standard height today of $2.1 \mathrm{~m}$.

Skirtings will need to be removed and refitted on damp walls as the timber wall plugs will be rotted. Replace the plugs and refix or replace skirting if also rotted.

\subsection{Internal wall repairs: paper and painting}

Removing wall paper and old paints have their own problems. When removing wall paper remember the paper probably hides many faults- cracks, rising damp and drummy render and poor repairs.

Removing wall papers that are sealed or vinyl faced are extra difficult. Steam machines can be hired but a better method is placing thick wet newspapers on the walls, being very patient, then removing them. Two operations may be necessary but it's both cost effective and makes good use of old papers.

When removing paint, be aware of, and take precautions; if there are lead based paints. Council's can advise. Calcimine or lime based paints below newer layers of paint can fail completely when more layers of paint are added. Calcimine or lime wash paints must be removed through hand washing.

There are proprietary products on the market such as 'peel away' which work best when there are many layers to remove; again, a laborious task. If there are damp patches on the walls, (salt laden from rising or falling damp) these patches will show again. See note on rising damp above. Moisture in absorbent surfaces will cause paint to fail. Acrylic and oil paints trap moisture in walls. If possible remove and replace previous poor repairs to plaster when these are revealed, especially if they are in cement render instead of a traditional lime based render.

\section{Current and future work}

The case study project still has a considerable way to go. Tenders for the additions have been called and it is expected work will continue for another 6 months. The following work is in hand:

\subsection{New services: plumbing and electrical}

Older houses have very poor level of services as these were usually retro fitted after initial construction. Considerable thought needs to go into re-fitting these services but it is an opportunity to 
- Upgrade the electrical work including the electrical board and wiring to make them safer and less visible. Add telephones, TV and smoke detectors. In the Case study the electrical switch board was large and unsightly, next to the main entry door. It will be relocated to the side of the house and all wiring re- run. Additional power points and light switches will be added and chased into the walls, existing ones upgraded. Pull chords for light switches will be used to minimise wall chasing.

- New plumbing will be introduced into the existing house. The work on the retro fit bathroom has commenced and allowed access to the underside of the floor where ventilation opening were inspected.

\subsection{The setting}

It is proposed to restore a Victorian era appearance to the front of the house by reinstating a posted verandah, and a central path, maximising the symmetry of the facade. This will be complemented with a picket fence.

\section{Conclusion}

Heritage incentives to encourage the retention of older house stock rely heavily on grants and free advice. These incentives are more effective when run together. Heritage advice is based on current best practice knowledge tempered with experience. The aim of this project was to enable the adviser to have genuine relevant field experience and so be more empathetic with the home owner /builder and to able to discuss alternatives in conservation works.

This practical guide shows the value of following a process. Researching the history of the house through documentation and the physical fabric, and understanding what is significant about the house before proceeding. Then developing a plan that is environmentally sustainable, retaining the most significant fabric, but opening the house to opportunities for solar access, thermal comfort, water conservation and efficient use of energy.

It is practical and possible for home builders wishing to do much of the work themselves. They can take advantage of firms offering traditional materials such as pre packaged lime mortar, products and equipment to strip paint, poultice walls, aid ventilation and add insulation, and can discuss their plans and options with their local heritage adviser.

\section{References}

[1] Bingham, Janet. 'BR Heritage Fund Statistics'. Bathurst Regional Council. NSW Australia.

[2] Croft, Sinclair. 'Giving our past a future: comparing NSW Local Government Heritage Incentives with Global Practice.' Charles Sturt Uni. Albury, NSW. 